\title{
EXPRESSION OF PERSONALITY THROUGH DRESSING
}

\author{
Jordan Efremov ${ }^{1 *}$, Marija Kertakova², Vangja Dimitrijeva Kuzmanovska ${ }^{1}$
}

\author{
${ }^{1}$ Art Academy, University "Goce Delcev“, Stip, Republic Nort of Macedonia \\ ${ }^{2}$ Technological and Technical Faculty, University „Goce Delcev”, \\ Stip, Republic Nort of Macedonia \\ *e-mail: jordan.efremov@ugd.edu.mk
}

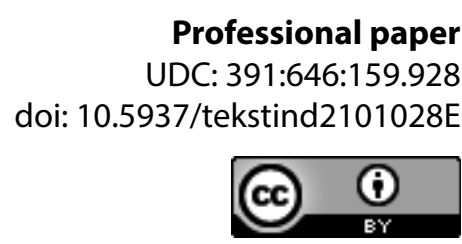

\begin{abstract}
Clothing and fashion allow the multiplication of multiple personalities into one human being. The tendency to be "someone else", even if it is only with some detail in the clothes, is based on the possibility of transformation of the individual. That transformation is done by masking man, more precisely, the aspiration of one person to transform at least for a short period of time. The possibilities offered by fashion, that a person can be someone else with the help of clothes, cosmetics or make-up are really great. One of the most important functions of clothing and apparel is to achieve a sense of spiritual balance. In fact, with the help of clothing, certain shortcomings of a person are compensated and, in that way, a certain psychological balance is achieved. The extent to which following fashion reduces the feeling of inferiority is seen in the fact that in most countries fashion is most closely followed by young people and immigrants, because it seems to them that dressing according to the latest fashion equals them with others.
\end{abstract}

Keywords: fashion, clothing, personality typesl, socio-cultural environment, psychology.

\section{IZRAŽAVANJE LIČNOSTI KROZ ODEVANJE}

Apstrakt: Odeća i moda, omogućavaju umnožavanje nekoliko različitih ličnosti u jednom čoveku. Težnja da budemo "neko drugi", čak iako je to samo sa nekim detaljima u odeći, zasniva se na mogućnosti naše transformacije, tačnije transformacije nekog pojedinca. Ta transformacija se na neki način vrši maskiranjem čoveka, tačnije težnjom jedne osobe da se transformiše bar na kratak vremenski period. Mogućnosti koje nudi moda, tako da osoba uz pomoć odeće, kozmetike ili šminke bar na trenutak ili u nekom određenom periodu, može biti neko "drugi", zaista su sjajne. Jedna od najvažnijih funkcija odeće, je postizanje osećaja duhovne ravnoteže. Zapravo se uz pomoć odeće nadoknađuju određeni nedostaci kod osobe i na taj način se postiže određena psihološka ravnoteža. U kojoj meri praćenje mode smanjuje osećaj inferiornosti, vidi se po tome što u većini zemalja modu najviše prate mladi ljudi i imigranti, jer im se čini da ih oblačenje po poslednjoj modi izjednačava sa drugima.

Ključne reči: moda, odevanje, tipovi ličnosti, sociokulturno okruženje, psihologija.

\section{INTRODUCTION}

One of the most important components of fashion and clothing is that every person strives to express themselves in some way through clothing. The different ways of dressing, then the different psychological characteristics of different people, lead to the fact that a person can successfully express the characteristics of his mental structure, precisely through clothing and fashion. The expressiveness one of the most important functions of clothing and outfit is to achieve a spiritual balance. In fact, through clothes and clothing, certain shortcomings in the person are supplemented and, in that way, a certain, as we said, spiritual or psychological balance is achieved.

There are many possibilities and ways to achieve these goals through dressing, such as masking the person during dressing, then achieving spiritual and 
psychological balance through clothing and compensating for that feeling of inferiority through clothing.

The social status of the person can be successfully displayed through the dressing. Clothes can show a person's status through many different things, for example, through the colors of the clothes, through its quality and its price, and even through the material from which the clothes are made i.e., as we have said through its quality. It has been proven by several scientists that clothes, in one way or another, can capture and display the social status of a person, but we will talk about that in the following text of this article.

New research also shows that the style of dress affects a person's thinking. Whether it be smart casual, formal, business formal or casual, each of these ways of dressing inspires and motivates different ways of thinking in the person who practices such ways of dressing.

In this article we will try to explain these few aspects of how and in what ways a person can express himself through fashion, through clothes and through dress.

\section{PERSONALITY MASKING AND DRESSING}

Clothing and fashion, as we have said, enable the multiplication of several personalities in one human being. The tendency to be "someone else", even if it is only with some detail in the clothes, is based on the possibility of transformation of the individual. That transformation is done by masking man. The possibilities offered by fashion, so that a person with the help of clothes, cosmetics or make-up can be someone else are really great [1].

Disguise while dressing allows the individual to move towards greater freedom. However, in the opinion of some analysts, disguise often entails hypocrisy.

In fashion disguise, a person transforms and pretends to be someone else, who may or may not exist. However, fashion disguise is similar to just one type of game and this kind of disguise is not intended, to lie or deceive someone, but offers relaxation of the person and offers the opportunity to discover oneself as a new person. Because of that man feels and behaves much freer. The unit through this "game" of dressing, transforms into someone else, without losing their identity.

For example, if you compare the appearance of a hippie with the appearance of a Chinese red guard, you can see the complete contrast. The clothes and the way of dressing completely modify the human appearance.

Different socio-cultural environments and different situations dictate the fashion and processes of masking the individual, who tends to present himself in a new style. Clothing, make-up, coloring or makeup, wearing a beard or mustache in a man, as well as
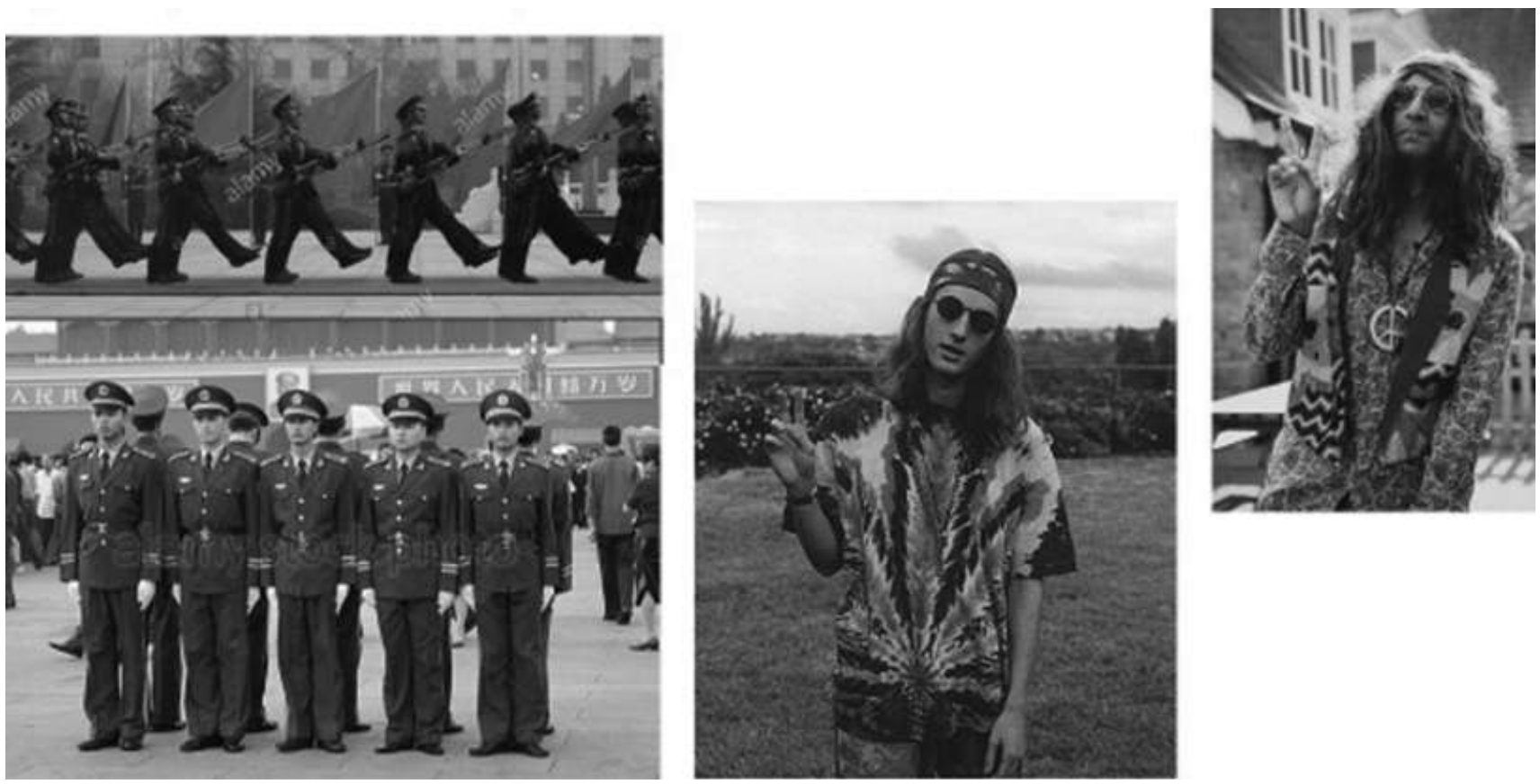

Figure 1: Karen J. Pine. Mind What You Wear: The Psychology of Fashion. Kindle, 2014, The clothes of the red guard in China, compared to clothes from the period of the hippie movement 

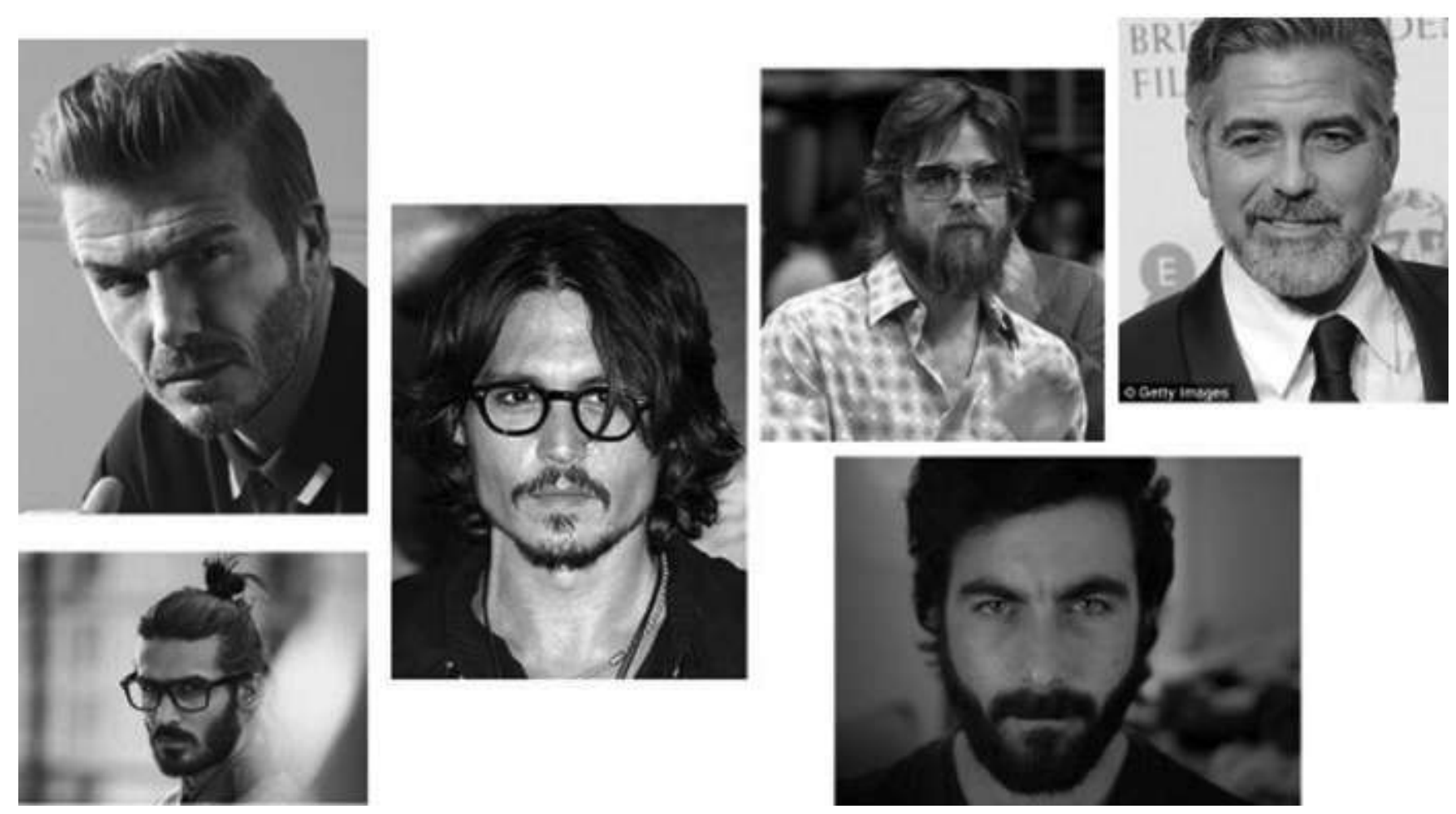

Figure 2: Karen J. Pine. Mind What You Wear: The Psychology of Fashion. Kindle, 2014, Masking the man with a beard and mustache

some other elements of make-up, often have exactly that purpose for masking the person [2].

Fashion offers great opportunities for an individual to be able, at least "formally" through clothing, to approach and identify with some type of personality, who dominates at a certain time and in a certain space. However, by exploring one's own expression, in this game it is necessary to find the right measure and limit, which will ensure the person does not neglect his other own qualities and lose his identity.

\section{ACHIEVING SPIRITUAL AND PSYHOLOGICAL BALANCE THROUGH CLOTHING}

One of the most important functions of clothing and apparel is to achieve a sense of spiritual balance. In fact, with the help of clothing, certain shortcomings of the person are compensated and, in that way, a certain psychological balance is achieved. In this case it is about one, if we can say compensatory function of clothing, which is a certain mechanism by which the body defends itself. If a person has a feeling of inferiority, she often tries to make up for the shortcomings that negatively affect her through clothing and fashion. This function of clothing, to compensate for certain elements or shortcomings, is put in the fore- ground through the very meaning that a costume has for the individual [3].

The world of culture is important to man. It is a continuous process in which the creative thought and the imagination are intertwined with what has already been created, and in that way they themselves are realized, more precisely, materialized. Because in modern society, spiritual culture is increasingly expressed through material forms. That is why abstract scientific and artistic ideas also penetrate material products. So, such ideas shape objects for everyday use, change the means or tools for work, residential buildings, machines, clothes, human relations and more.

This means that the material objects and products where the clothes belong, but also the other products that we have mentioned, are in fact signs that carry with them a certain meaning. Clothes are a sign that indicates the person who wears them.

It emphasizes his social status, his class, his ethical, urban, rural or some other affiliation. So, the costume is a kind of sign that indicates certain meanings. Every person can communicate with other people with the help of signs, including clothes. Of course, the signs should be different from each other. Namely, the clothes that are conditioned by the class, ethical or professional determinants, should be different 
from the clothes through which the person wants to compensate or make up for certain shortcomings. In such cases, the dress and clothing, as we have already said, serve as compensation, in order for the person to be psychologically confirmed.

Compensation has a role to play in the need for prominence and the desire to come out of anonymity. Given that fashion often changes, every fashion change opens a "new chance" for those people who think that the fashion that has passed may not "fit them well", more precisely it does not suit them, which of course in some way reduces their inferiority [4].

\section{COMPENSATING FOR THE FEELING OF INFERIORITY THROUGH CLOTHING}

To what extent, following fashion reduces the feeling of inferiority is seen in the fact that, especially in the United States, young people and immigrants follow fashion most closely, because it seems to them that dressing according to the latest American fashion equals them with other Americans. It somehow reduces their uncomfortable but basically justified feeling that they are second- or third-class citizens in that country. The situation is similar with the smaller cities in a country i.e., in the cities from the interior in relation to the capital. In fact, following the fashion there is often more pronounced than in the capital, or in the larger centers.

This phenomenon is exactly because of the feeling of inferiority or the so-called "province complex" and the desire to equalize with the big centers. But there are smaller cities where the textile industry is actually developed, so that is why such textile centers do not have this complex of inferiority compared to the big cities. It is so, because of the fact that exactly from these small textile centers the latest fashion trends are created intended for an entire country, and beyond, more precisely, fashion pieces are exported to other countries in Europe and in the world [5].

There are various reasons why a person has a feeling of inferiority, which he wants to suppress and complement through clothing. For example, when a person in an environment can't affirm himself through certain values, then he seeks the expression of affirmation through fashion i.e., through clothing. The person through the signs of the costume, strives to create a certain meaning which is a surrogate, i.e., copying a certain status, beauty or prestige in a certain environment. In fact, the way of dressing, should in some way serve to gain some recognition from the environment towards that person.

Often the costume is a sign that indicates a certain status and speaks about the psychology of the person. But the costume can often be a false copy of both the status and the psychology of that person. All other functions of clothing such as protective, erotic, aesthetic and others can actually be included or categorized in that compensatory or additional function of clothing. It conditionally provides the person with a spiritual and psychological balance in certain situations.

For example, bizarre and striking clothing is often accompanied by inappropriate behavior, such as arrogance, bullying, etc. This is usually just a manifestation of a compensatory and compensatory behavior. Namely, in this way a person wants to draw attention to himself and thus alleviate the feeling such as: "I am nobody and nothing", from which feeling most often suffer the most immature "heroes" of a society. But compensation or compensation in a person's behavior does not always have to be socially undesirable and negative. There are cases where this encourages the weaker to become stronger.

For example, a frail and sick boy may be encouraged to become the best student in his class. In that way, the boy will make up for his inferiority to the stronger children if he were with them on a meadow or on a playground.

In such cases it is a matter of super compensation, it is a mechanism that encourages people who have a real problem. In fact, in this way, with persistent exercise, they manage not only to compensate and overcome that problem, but to achieve even more than the others, i.e., to overcome other people [6].

\section{DEMONSTRATION OF STATUS AND PERSONALITY, MODERN TYPES OF STATUS AND POWER}

How can clothes show a certain status? Clothes can show a person's status through many different things, for example, the colors of their clothes, the price of the clothes, and even the material from which those clothes are made. For example, according to some scientists, clothes still show your status in one way or another. For example, clothing colors are often used to mark or label people, so many people will assume that black will be the color of Gothic style, but of course this may not always be true. 
However, in the Tudor period, which is historically in English history between 1485 and 1558 and corresponds to the Tudor dynasty, also known as the Elizabethan period, the color of clothing was used for many purposes. Then, for example, the color purple was allowed to be worn only by the royal family, so it was used to determine the social status of a certain person, i.e., how much wealth and financial resources he possesses.

Many different materials can be used to make different types of clothing. But they all cost differently, from polyester and nylon, which are among the cheapest, to silk, which is one of the most expensive. The more expensive materials were usually carried by royal families or some wealthier people, so that they could show how much money they had and how much wealth they possessed.

The cost of clothing is determined by many different things, and one of them is for example the price of the materials used. Throughout history, rich people - the royal family and similar - wore more expensive clothes, to be able somehow to stand out from the poor people. Nowadays, such status differentiation between people is done through uniquely designed clothes, which many people buy in order to stand out from the rest in some way.

The way we dress is the way we express our personality. Every person who wants to be nicely dressed, tries to have an authentic, unique and original style, which is reflected through the use of certain colors and other fashion details depending on the person. Also, through the clothes and through the way people dress, sometimes it can be emphasized what their preoccupation is or to emphasize what they should emphasize and express if they should wear the uniform for example. So, in the army, maybe many things can be expressed according to the costume of the clothes and according to its color - the camouflage. Dressing children in some schools in uniform is also a way for that school to be different from another school and to stand out with its different individuality and different occupations [7].

\section{CLOTHES CHANGE ACCORDING TO THE WAY THEY ARE WORN BY A PERSON}

If you have ever seen the rehearsal process in a play, then you know how powerful the costumes themselves can look in it. Even at a very early stage of the project, professional actors will come to prac- tice the role dressed in certain pieces of clothing, which is made for that purpose, in order to feel more immersed in the character of the role. It could be old shoes, then a long, heavy skirt or something. These pieces of clothing help the actors a lot to get exactly that real impact on the role, to get the right motivation and benefit, to look convincing and to be able to reach the zenith of the stage through the play.

A few weeks later, when the actors are closer to the premiere, they already have the real rehearsal with their real costumes. It is quite amazing, but also nice to see how the real clothes that the actors wear at the performances, leads to a completely new level of presentation and to see how those clothes transform the actor into the character. In fact, the costumes that the actors wear in the play complement and shape the overall theatrical act on stage. As business professionals in any field, we can actually learn a lot from this example.

One may or may not like it, but it is an indisputable fact that the clothes and the way it is presented and presented by a certain person, says a lot about that person. It is very important that the person knows how to wear the clothes that are on it. To be able to take off the clothes he is wearing in style. The question is not whether the person is very obsessed or preoccupied with fashion, but how that person consciously or unconsciously communicates with the environment through her fashion choices when dressing. Just as the actor in the real costume moves

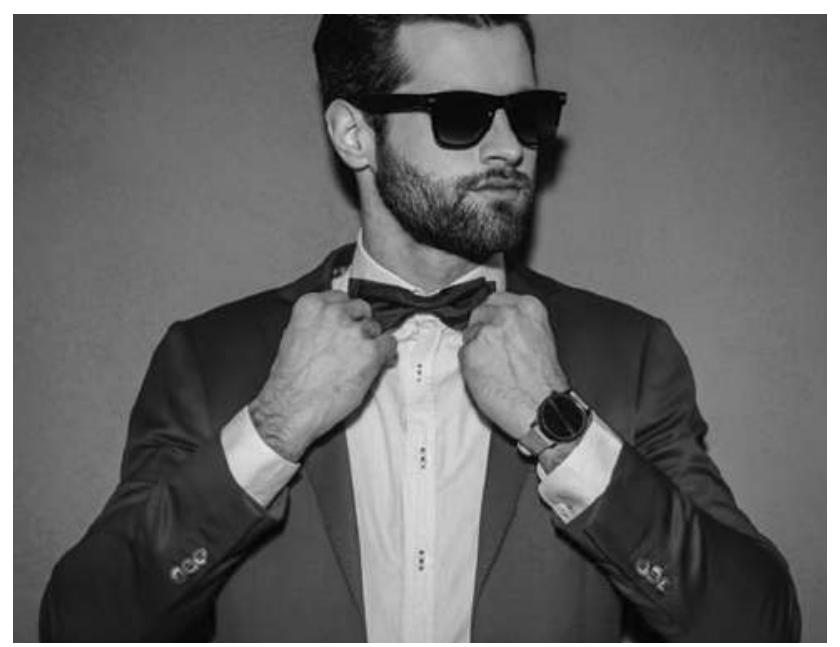

Figure 3: Karen J. Pine. Mind What You Wear: The Psychology of Fashion. Kindle, 2014, It is very important that the person knows how to wear the clothes he is wearing and to be able to show it in style. 
and speaks differently, so the person does it every day in everyday life [8].

The clothes tell a certain story about that person. If a person wants to show that her work is clean, delicate and precise, then she will dress in clean fashion lines, in elegant suits, with an emphasis on sharp folds and lines, with an emphasis on shoes and a tie. Even the way the glass is held, for example, can speak for you and your work.

\section{THE IMPORTANCE OF DETAILS IN CLOTHIG}

Research shows that you can learn a lot about a person, about their political affiliation, about their status, about their age, about their income, just by simply noticing a detail of their clothes. It is considered that the most common indicator to recognize some of these features of a person, for example, is to notice his shoes.

It can also be seen that sometimes high-ranking politicians, with the intention of approaching the working class, are often dressed very modestly and simply. For example, former US President Barack Obama often addressed the crowd of working-class Americans, without a suit in only one shirt, with the sleeves bent halfway up his arm. In that way, the president actually indirectly informs the audience, i.e. the people that he is also a great worker.

A few years ago, the forty-fourth page of the dress code was discovered in the Swiss bank UBS, which was attacked by viruses and hacked, and it revealed many interesting details about the dress code in the Swiss banks. Namely, all the obsessive provisions in the dress code were revealed, which are defined and written in detail.

Starting with the reasonable ones, such as: If you wear a watch, it suggests security, and that accuracy is due to the great care you have for the company, down to the purely invasive or imposed rules that were imposed on employees. Starting with how they should shower, how they should use perfume or lotion, how to wear underwear and suggestions that they should not eat garlic during the week.

Those who wrote these dress codes at this bank may have been control freaks or weirdos, but UBS got a certain image that way, and that is that every detail of a visual representation of an employee of this company reflects something about themselves.

When a woman dresses or arranges her hair, she should consider what it says about her and whether it is in line with the message she wants to send. It is not a question of whether she is right or not, but simply of the context in which it is perceived [9].

A man's tie can give the impression that he looks confident and in some way such a look is rooted in tradition. This can be a very important fashion rule in an investment company, where clients want to know that you are serious about managing their capital. But also, by blindly adhering to that fashion code with a tie, you can create the opposite effect. Specifically, this way of dressing can give some of the investors the impression that you are an outdated type, which may be resistant to the changes that the investor would require. Such a strict and formal dress can also sometimes seem inappropriate for a young investor who wants to create a modern company, with technological changes, which are a prerequisite for the technological development of that company.

\section{CLOTHING HAS AN EFFECT ON OUR THINKING}

For increasing self-confidence and increasing the feeling of self-proof, of course very important is dressing in the so-called smart clothes. But the style of dress costs much more than just sending certain messages to our minds and to those around us.

New research shows that dress style actually affects the way we think. One study found that a professional suit, whether male or female, enhances people's abstract thinking and gives them a broader perspective on their thinking. So, a tie could actually be a key element in expressing your business creativity.

"The formality of the clothes can affect the way other people perceive a person. The formality of the clothes also affects how people perceive themselves. But it can also influence other people in making specific business decisions. "Such an impact actually refers to very important situations, and one of the most significant is the impact on the negotiation process, especially in those business contacts," the study said.

Professional clothing also in some way creates a status distance in professional work. When a person, for example, has a kind of status distance through clothes, then he tries to think and communicate in an abstract way with the people he works with, i.e., by using more distant and in some way abstract terms. In such socially and status-driven circumstances, for example, we address those people by the name or title 
they have, rather than by addressing them personally, or rather by their personal name.

Even when controlling the socio-economic status of certain schools, the students in those schools where they wear more formal clothing showed a stronger inclination towards abstract communication, i.e., a more inclination towards a formal relationship with teachers [10].

\section{CREATING A STRONG SHORT - LIVED OR FLASHY IMPRESSION THROUGH CLOTHING}

Usually, we all process visual details instantly through a process called flash impression. This is when the brain makes judgments in milliseconds based on a new stimulus provoked by a particular sight. It often happens even without us knowing or being aware of it. We can sometimes get the feeling that we do not trust someone else or vice versa, that someone else is much more confident and secure than us, and often we are not even aware of it.

This feeling in the stomach is often called intuition, premonition or first impression. It is really part of the very fast mental process of the so-called flash scan of a certain scene in our brain and is similar to when, for example, we would constantly and daily evaluate the quality of books according to their external design or cover [11].

That is why we need to choose our appearance carefully. Appearance does not only include our clothes, but also the accompanying accessories, then the hairstyle, the smell, the posture, the tone of voice, the energy level with which we move, talk, etc.

In fact, we should imagine the person we would like to be in any situation. Then we have to get dressed, tidy our hair, i.e., hairstyle, to sort out certain fashion accessories and to act in a way that will help us mentally enter that imaginary person.

If we go somewhere to do a certain thing, then we should wear a striking color, we should conditionally say "roll up our sleeves" and speak boldly with an accent tone and diction. If we are going to have a certain social communication, meeting a certain person at a gala evening, at an event or a party, then we need to be persistent, but to speak in a gentle tone. Women can afford more open and relaxed clothes, but with moderation.

It is the same as when, for example, we are going to have fun somewhere on a long weekend and then we intentionally bring less food with us, and thus we will probably be able to avoid those excess comforts that we would have there.

Taking self-control with the intention and purpose of how we will be dressed and what our appearance will be, is a good step in strengthening ourselves, in achieving our goals. It is an opportunity to live a more lucid or meaningful life, in which our decisions will come first. That is why we need to be careful and know that the whole world is a kind of wide and open stage [12].

\section{CONCLUSION}

From all the above observations that clothing can have a great impact on a person to express their personality, it can be concluded that there are more ways and more opportunities to achieve such expression through clothing. In fact, it is sometimes not the end goal of a person. On the contrary, if we can say so, the self-expression of the person through fashion and clothing, usually happens intuitively, without any intention and purpose, but it usually depends on the character traits of the person, then it depends on his creativity, meaning or talent that a person possesses it for his fashion expression, and of course from the financial possibilities, which are provided to such a person to achieve it. However, through all these conclusions, it is once again proved that fashion and clothing are a phenomenon that penetrates deep into the aesthetic and psychological characteristics of the person, so all these components make fashion even more exciting and irresistible.

\section{REFERENCES}

[1] Pine K.J. (2014). Mind What You Wear: The Psychology of Fashion,Kindle.

[2] Crane D. (2001). Fashion and it's social agenda's: class, gender and identity in clothing, University of Chicago Press.

[3] Book:Todorović A. (1974). Sociologija masovnih komunikacija, Gradina, Niš.

[4] Barišić I.M. (2006). Moda i odevanje, Glasnik Etnografskog instituta SANU, 1, 245-257.

[5] Malcolm B. (2002). Fashion as Communication, Routledge.

[6] Roland B. (1990). The Fashion System. University of California Press.

[7] Paulin W. T. (2001-2006). Theories of Fashion Costume and Fashion History. 
[8] Efremov J. (2019). Psihologija na oblekuvanje Psihologija odevanja, izdavač Univerzitet "Goce Delčev" - Stip.

[9] Ranisavljev - Kocareva M. (2009). Moda i komunikacija, Tekstilna industrija, 57(4-6), 27-29.

[10] Dorfles Gillo (1997). Moda, Golgen marketing, Zagreb.

[11] Elijade M. (1981). Okultizam, magija i pomodne culture, Zagreb.

[12] Vuković M., Urošević S., Vuković A. (2011). Neverbalna komunikacija i stvaranje ličnog i profesio- nalno identiteta preko odevanja, Tekstilna industrija, 59(2), 27-32.

Primljeno/Received on: 29.12.2020.

Revidirano/ Revised on: 16.02.2021.

Prihvaćeno/Accepted on: 19.02.2021.

(c) 2021 Authors. Published by Union of Textile Engineers and Technicians of Serbia. This article is an open access article distributed under the terms and conditions of the Creative Commons Attribution 4.0 International license (CC BY) https://creativecommons.org/licenses/by/4.0/) 